\title{
Dealing with Defeat
}

\section{Dutch Brazil (1624) and English Jamaica (1655) in Newspapers from the Habsburg Netherlands}

\section{TIFFANY BOUSARD}

Tiffany Bousard is a PhD-candidate at Leiden University Institute for History and examines Atlantic news which circulated in the Habsburg Netherlands during the period 1580-1680. By focusing on different kinds of news reports, she maps out divergent, co-existing narratives on the same Atlantic events. Her research, which is part of prof. Michiel van Groesen's Nwo project Covering the Ocean - Newspapers and Information Management in the Atlantic World, 1580-1820, aims to grasp the plurality of both early modern news and the media landscape in the Southern Netherlands.

\begin{abstract}
Covering defeat or disaster in print required considerable journalistic finesse in the Southern Netherlandish news market, since the primary role of privileged courantiers in the Habsburg empire was to provide accounts of royal successes. This article investigates the ways in which the Antwerp printer-publisher Abraham Verhoeven and Brussels newsman Pierre Hugonet covered two main Atlantic events with a negative outcome for the Habsburg monarchy: the Dutch invasion of Brazil in 1624 and the English capture of Jamaica in 1655 respectively. By comparing these major Atlantic news stories, this article will deepen our understanding of how these gazetteers, who differed in professional background and operated decades apart, dealt with defeat suffered in the Western Hemisphere. It will argue that both newspapermen presented the Habsburg setbacks in a strikingly similar way, using largely the same editorial and rhetorical strategies. This suggests that there appeared to be a 'discourse of defeat' in the Habsburg Netherlands, which newspaper publishers adapted to satisfy both their customers and central authorities throughout the seventeenth century. This 'discourse of defeat', however, was not confined solely to the southern provinces, as Dutch and English courantiers employed similar tactics to cover up bad news. Therefore, government control and pre-emptive censorship, which continue to be considered dominant features of the Southern Netherlandish media landscape, appear to have played a less decisive role in the way newspaper publishers covered defeat than hitherto has been presumed.
\end{abstract}

Keywords: newspapers, Habsburg Netherlands, Abraham Verhoeven (1575-1652), Pierre Hugonet ( $\uparrow 1667)$, Dutch Brazil, English Jamaica

DOI 10.18352/emlc.60 - URL: http://www.emlc-journal.org

Publisher: Stichting EMLC, supported by Utrecht University Library Open Access Journals | The Netherlands Copyright: The Author(s). This work is licensed under a Creative Commons Attribution-NonCommercial 4.0 International License. 


\title{
Dealing with Defeat
}

\section{Dutch Brazil (1624) and English Jamaica (1655) in Newspapers from the Habsburg Netherlands}

\author{
TIFFANY BOUSARD ${ }^{1}$
}

Over the course of the seventeenth century the Habsburg monarchy suffered two major territorial defeats in the Atlantic world, which both seriously threatened its supremacy overseas. In May 1624 the Dutch swiftly invaded Salvador da Bahia, the capital of Portuguese Brazil, as part of the seemingly interminable Dutch Revolt, which had been resumed after the ending of the Twelve Years' Truce with Spain in 1621. ${ }^{2}$ In July 1655, less than a year after the Portuguese had finally regained their former Brazilian settlements from the Dutch colonists, the English followed the Dutch example. As part of Oliver Cromwell's so-called 'Western Design', the English took Jamaica from the Habsburgs. ${ }^{3}$ Both 1624 and 1655 were challenging years, not only for the Spanish King Philip IV, who saw two of his imperial possessions pass into rival European hands, but also for the Antwerp printer-publisher Abraham Verhoeven (1575-1652) and Brussels newsman Pierre Hugonet $(\dagger 1667)$, who had the difficult task of reporting on these defeats in their newspapers.

Covering defeat or disaster in print required considerable journalistic finesse in the Southern Netherlandish news market. ${ }^{4}$ The primary role of newspapermen in the Habsburg empire, like Verhoeven and Hugonet, was to provide accounts of royal successes. While Verhoeven had received an exclusive license to print Dutch-language news from 1620 until the end of his career in 1634 for that purpose, Hugonet was granted a similar monopoly on French-language news publishing from 1649 onwards. ${ }^{5}$ In their newspapers, which were pre-emptively censored by local authorities, the two privileged courantiers systematically had to spin setbacks as being in favour of the Habsburg monarchy, without losing their credibility and their readers or the patronage of the court in Brussels.

1 This research was funded by Nederlandse Organisatie voor Wetenschappelijk Onderzoek (Nwo). I would like to thank Michiel van Groesen, Esther Baakman, Arthur Weststeijn, Johannes Müller, Helmer Helmers, Arthur der Weduwen and the anonymous reviewers for their valuable comments and suggestions on earlier drafts of this piece.

2 Israel, The Dutch Republic, 127-134.

3 Pestana, The English Conquest of Jamaica, 1-14.

4 Der Weduwen, 'The Battle of the Downs', 6.

5 Arblaster, From Ghent to Aix, 74, 220-221. 
In order to publish both politically acceptable and commercially relevant news stories, both Verhoeven and Hugonet employed various editorial and rhetorical strategies. A couple of studies over the past two decades have provided important information on how especially Verhoeven, who was the first to enter the newspaper business in the Habsburg Netherlands, managed bad or delicate news in his newspaper. ${ }^{6}$ Recent research by Arthur der Weduwen has shown that Verhoeven's direct successors, the Antwerp courantiers and competitors Willem Verdussen and Martin Binnart, employed similar tactics when reporting Habsburg defeat in their corantos. ${ }^{7}$ The strategies of Hugonet, by contrast, who is considered the Brussels counterpart of Verhoeven, have only received little attention so far. ${ }^{8}$ Up to now, historical scholarship on the subject has tended to focus mainly on the underreporting or withholding of Habsburg setbacks, largely neglecting the way(s) in which the courantiers did present these unfortunate events. Also, research to date has been mostly restricted to defeats on the Continent, probably on the assumption that distant setbacks could be more easily ignored or obscured than those nearby. ${ }^{9}$

Facing pre-censorship and a negative outcome for the Spanish Crown, how did Verhoeven and Hugonet cover the Dutch invasion of Bahia (1624) and the English capture of Jamaica (1655) respectively in their newspapers? Did both monopolists, who not only differed in professional background and (intended) readerships, but also operated decades apart, deal with defeat in very similar or totally different ways? And, how can differences or similarities among the Antwerp and Brussels newsman be explained? By answering these questions, this article will deepen our understanding of how Southern Netherlandish courantiers dealt with defeats suffered in the Western Hemisphere, showing that they were received with a similar caution as European setbacks. Also, it will shed new light on two major Atlantic news stories, which hitherto have been studied mainly from the victor's point of view. ${ }^{10}$ The accounts of Verhoeven and Hugonet, however, offered - and still offer - an interesting counterpoint to the triumphant accounts of the Dutch courantiers about Bahia and of the English newsmen about Jamaica. In comparison with the Dutch and English corantos, the Southern Netherlandish newspapers continue to be considered as mere propaganda tools. Nevertheless, Verhoeven's Nieuwe Tijdinghen and Hugonet's Relations véritables were first and foremost commercial products, offering many contemporaries in and outside the southern provinces a 'main window to the wider world'. ${ }^{11}$

\footnotetext{
6 Van Damme and Deploige, 'Slecht nieuws, geen nieuws', 1-22; Arblaster, From Ghent to Aix, 74-171.

7 Der Weduwen, 'The Battle of the Downs', 1-25.

8 Although the extensive research of Paul Arblaster offers occasional glimpses of Hugonet's editorial strategies, a systematic and (more) detailed analysis is still lacking. See Arblaster, From Ghent to Aix, 220-243.

9 Der Weduwen, Dutch and Flemish Newspapers, I, 53.

10 Michiel van Groesen systematically analyzed the extensive media coverage of the conquest of Bahia within the United Provinces in 1624. See Van Groesen, 'A Week to Remember', 26-49; Van Groesen, Amsterdam's Atlantic, 44-71; Nicole Greenspan examined the English reporting on the Hispaniola debacle and the subsequent capture of Jamaica in 1655 and the beginning of 1656. See Greenspan, 'News and the Politics of Information', 1-26, Greenspan, Selling Cromwell's Wars, 69-95.

11 Arblaster, From Ghent to Aix, 114, 159.
} 
The first section of this article provides background information on both the overseas events of 1624 and 1655, and the two Southern Netherlandish monopolists and their ventures. The second part treats Verhoeven's and Hugonet's coverage of the Dutch capture of Bahia (1624) and the English conquest of Jamaica (1655) respectively. The third and final section presents a comparative analysis of the two Atlantic news stories and the editorial strategies both courantiers used in their newspapers.

\section{The Habsburg Territories under Attack}

In the seventeenth century, the Habsburg dominance over their enormous Atlantic imperium was seriously challenged for the first time. In 1624, three years after the Dutch had resumed hostilities with Spain in the Low Countries, the West India Company undertook a successful attempt to open a second front in the Americas with an attack on Bahia, the capital of Portuguese Brazil. ${ }^{12}$ After a few months of secret preparations, the Dutch fleet set sail for the Cape Verde Islands at the turn of 1623. Here, the entire Dutch naval force, led by Admiral Jacob Willekens and Vice-Admiral Piet Heyn, assembled and, after a brief sojourn, continued its voyage to Bahia. In early May the Dutch fleet reached the Brazilian All Saint's Bay, from which the land army easily managed to capture Bahia on 10 May 1624. Although forewarned by the Spanish Crown, the Brazilian governor-general, Diogo de Mendonça Furtado, had not managed to take the necessary precautions in time. Several strategic miscalculations of the Dutch invasion force, however, seriously jeopardized enduring success in Brazil and less than a year later, the Habsburgs managed to repel the Dutch from their former Atlantic possession. ${ }^{13}$ Nevertheless, the Dutch had disrupted the status-quo in the Western Hemisphere, turning themselves into a force to be reckoned with.

Thirty years later, in 1654, the English followed in Dutch footsteps when Oliver Cromwell envisaged a bold plan, which became known as the Western Design: conquering the Spanish Americas. To this end a large English fleet, under the joint command of Generals William Penn and Robert Venables, set off in December 1654 to take the Caribbean island Hispaniola, the gateway to the Spanish Main. The Atlantic expedition, however, did not go as planned: In the spring of 1655 the English army suffered a devastating defeat at Santo Domingo, the capital of Hispaniola, but subsequently captured neighbouring Jamaica as a consolation prize. The bittersweet triumph narrowed the initial goal of the Western Design to the consolidation of their newly conquered territory. Although it would take the English several decades to turn Jamaica into a prosperous colony, they had gained a permanent foothold in the West Indies. ${ }^{14}$

12 Since the union of the Spanish and Portuguese Crown in 1580, the Habsburg imperium extended from the current southwest of the United States to the southern tip of South America. See Andrien, 'The Spanish Atlantic System', 55-56.

13 For more detailed information on the Dutch capture of Bahia and the subsequent Habsburg recapture, see: Klooster, The Dutch Moment, 38-41; Boxer, The Dutch, 21-27; Boer, 'De val van Bahia', 38-49.

14 For a more comprehensive overview of the English campaign in the West Indies, see: Pestana, The English Conquest of Jamaica, 1-14, 65-138. 


\section{Monopolists, Propagandists?}

The first half of the seventeenth century saw the emergence and flourishing of the newspaper trade in the Habsburg Netherlands. Cities of political, economic or cultural importance, such as Antwerp, Brussels, Bruges and - later on - Ghent generated vibrant news cultures in which the printed newspaper would gradually establish a firm position. To maintain the reputation of the Habsburg dynasty in these broadening media landscapes, the central authorities relied on traditional regulation mechanisms of the book trade: granting privileges or monopolies and imposing pre-emptive censorship. ${ }^{15}$ Abraham Verhoeven, an experienced printer-publisher from Antwerp, was the first to receive a royal license to print Dutch-language news in the southern provinces as a whole from 1620 onwards. This exclusive privilege effectively helped the Antwerp courantier to dominate the newspaper market. ${ }^{16}$ In 1649 , when Verhoeven was out of business and other newspaper publishers had filled the vacuum he had left, the Privy Council granted a similar license on Frenchlanguage news publishing to Pierre Hugonet, a French lawyer settled in Brussels. Although the monopoly boosted Hugonet's career as court gazetteer and professional opinion-broker, it did not prevent other well-established newsmen in Antwerp and Bruges from publishing their ventures after the Brussels newsman had entered the newspaper trade. ${ }^{17}$

While the two monopolists had different professional backgrounds and started their ventures decades apart, their newspapers showed several similarities (figs. 1-2). Both Verhoeven's Nieuwe Tijdinghen and Hugonet's Relations véritables were small multi-page booklets, in which the courantiers presented their reports in a more or less chronological order, offering the oldest news first. ${ }^{18}$ Unlike many other newspapers in the Low Countries which appeared on a weekly basis, the Nieuwe Tijdinghen and Relations véritables were often published more than once a week. Whereas Verhoeven adjusted his publication frequency to the (amount of) incoming news, Hugonet aspired to a strict periodicity, providing regular Saturday editions and additional issues on Wednesdays. ${ }^{19}$ Publishing more than one issue a week was not only a challenging task, but also an expensive undertaking in the first half of the seventeenth century. Both Verhoeven and Hugonet had each issue of their newspapers pre-emptively examined by local authorities, which slowed down their production. Also, the format of their newsbooks required several sheets of paper on a weekly basis at a time when paper was the most expensive part of the printing process. ${ }^{20}$

Despite the aforementioned similarities, the two monopolists sold their newspapers at different prices, in line with the readerships they targeted. The average cost of Verhoeven's

15 For more information on the seventeenth-century press regulations in the Habsburg Netherlands, see Arblaster, 'Policy and publishing', 179-194.

16 In the early 1620 's, Verhoeven's sole competitor was probably the Brussels printer-publisher Huybrecht (I) Anthoon, who launched the Nouvelles Neutrelles as a counter-weight to Verhoeven's serial. See Der Weduwen, Dutch and Flemish Newspapers, I, 49-50.

17 Arblaster, From Ghent to Aix, 220-221; Der Weduwen, Dutch and Flemish Newspapers, I, 56.

18 Unlike Verhoeven, Hugonet adopted a newsbook format without an eye-catching headline and decorative woodcut on the title page. See Arblaster, From Ghent to Aix, 221.

19 Arblaster, From Ghent to Aix, 105-107, 222-223; Der Weduwen, Dutch and Flemish Newspapers, I, 47.

20 Arblaster, From Ghent to Aix, 100-101. 


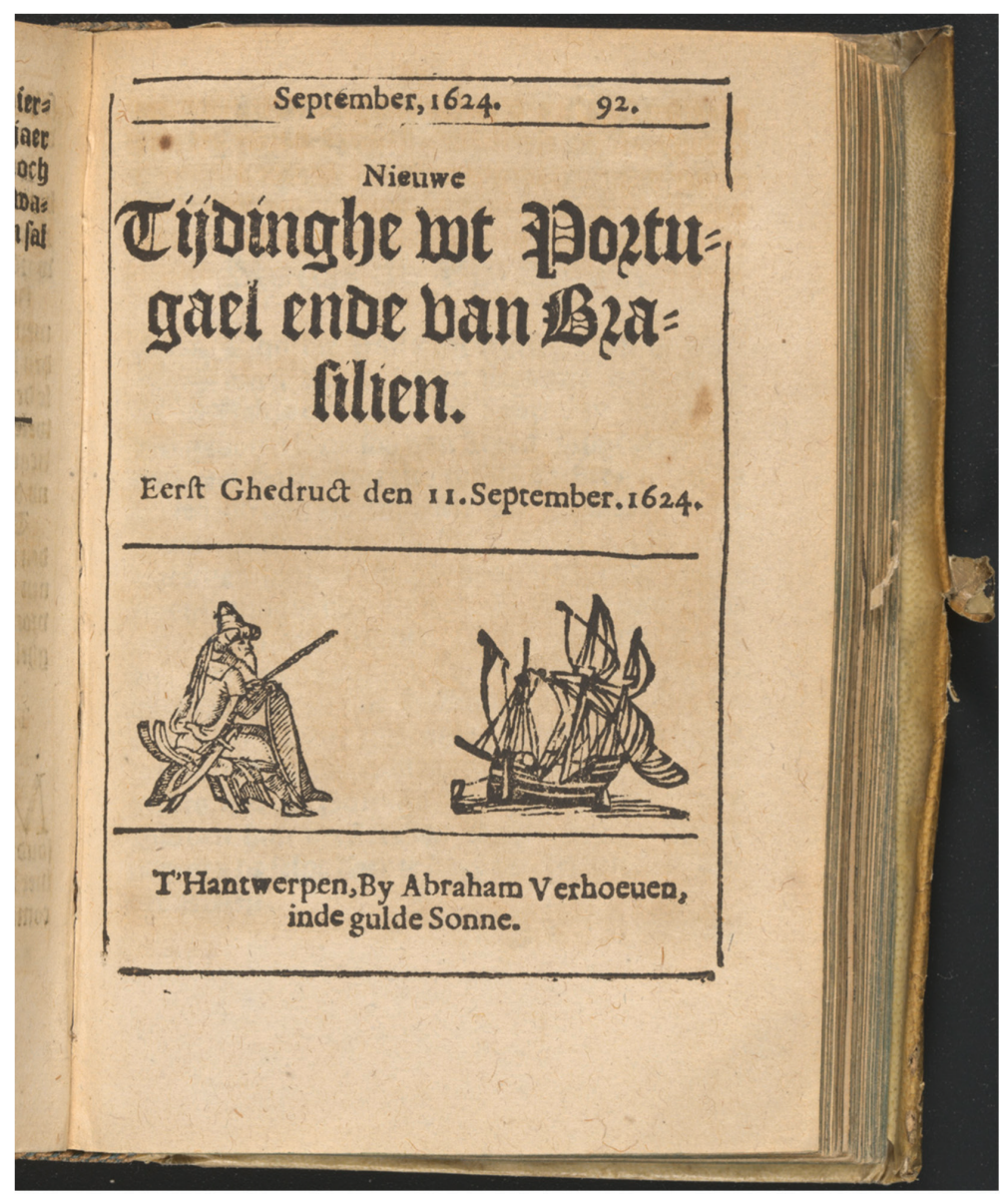

Fig. 1a Abraham Verhoeven, Nieuwe Tijdinghen, 11 September 1624 (no. 92), front page. Copyright Royal Library, Brussels.

Nieuwe Tijdinghen is still matter for speculation. Paul Arblaster recently estimated it at one stuiver per issue or six guilders per year, for on average 130 issues. ${ }^{21}$ Consequently, the regular purchasers of Verhoeven's newspaper probably belonged to the wealthy middling sort, such as merchants, master craftsmen, clergymen and army officers. A quite large diffusion beyond this group, however, cannot be ruled out. Buying every issue of the Nieuwe Tijdinghen certainly was an extravagance for many people in and beyond Antwerp, but purchasing just one issue a week, taking it in turn with family or friends, or buying it second-hand, made Verhoeven's newspaper an affordable luxury. Hugonet's Relations véritables, by contrast, was priced at three stuivers per issue. Located in the northern capital of the Habsburg empire, Hugonet mainly envisaged an international and courtly readership, as French was the first language of court members and councilors. To 


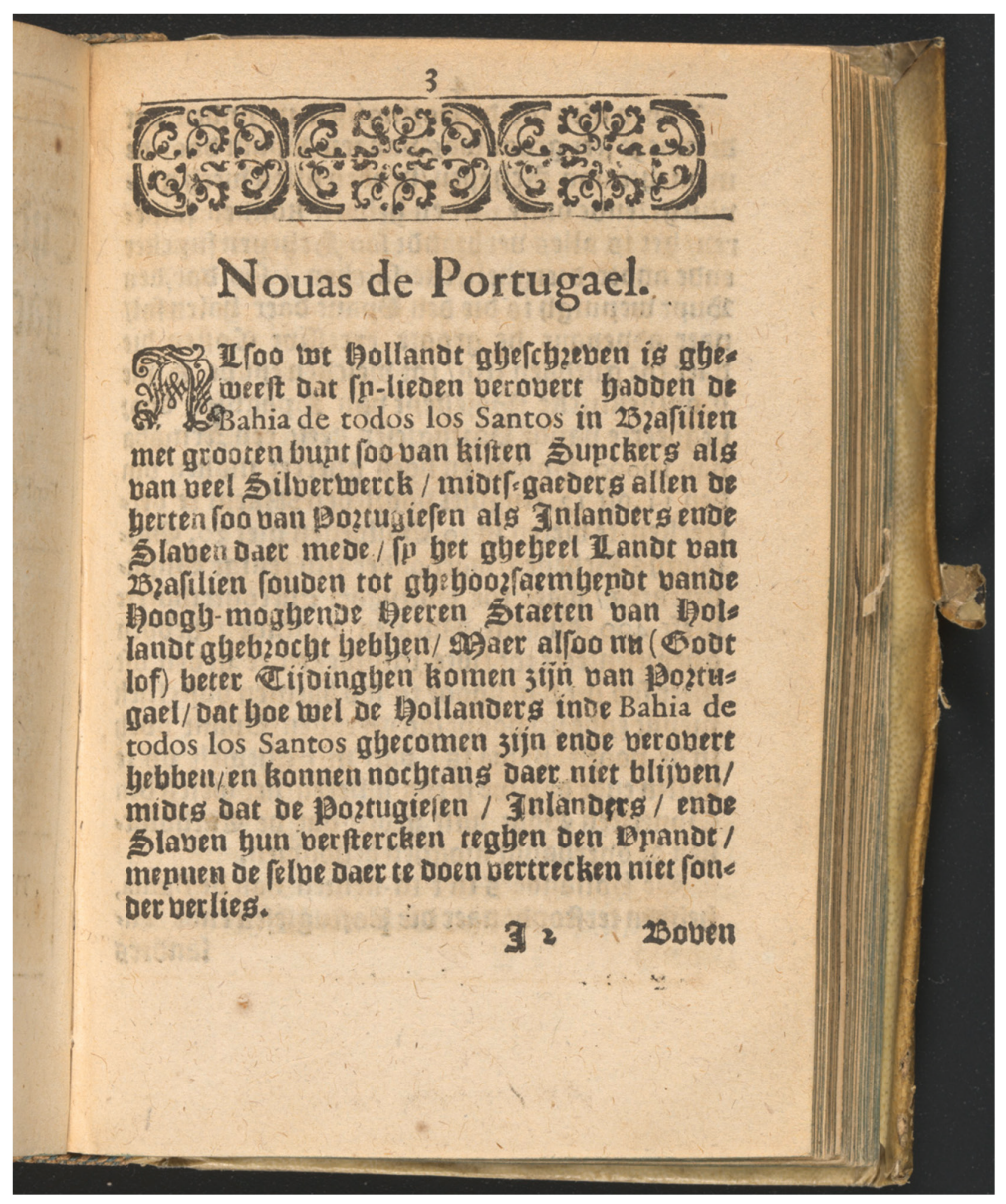

Fig. 16 Abraham Verhoeven, Nieuwe Tijdinghen, 11 September 1624 (no. 92), p. 3. Copyright Royal Library, Brussels.

meet the needs of the Dutch-speaking civic elite, Antwerp newspapers continued to be sold in Brussels throughout the seventeenth and eighteenth centuries. ${ }^{22}$

Serving both local and international readerships, the newsbooks of Verhoeven and Hugonet were - and still are - considered of great propaganda value to the Habsburg regime. As privileged courantiers, their primary role was to cover Habsburg victories in and beyond Europe, underlining royal power and piety. Simultaneously, the monopolists actively countered foreign news reports that promoted the perspective of the Habsburg adversaries. In the turbulent period of the Dutch Revolt, Verhoeven deliberately opposed the reliability and orthodoxy of his accounts to those of the Amsterdam printer-publisher Broer Janszoon. Hugonet, in turn, immediately launched himself into a running paper war with Théophraste Renaudot, the Parisian gazetteer. The Brussels courantier often openly claimed that he provided more accurate reports on the ongoing war with France 


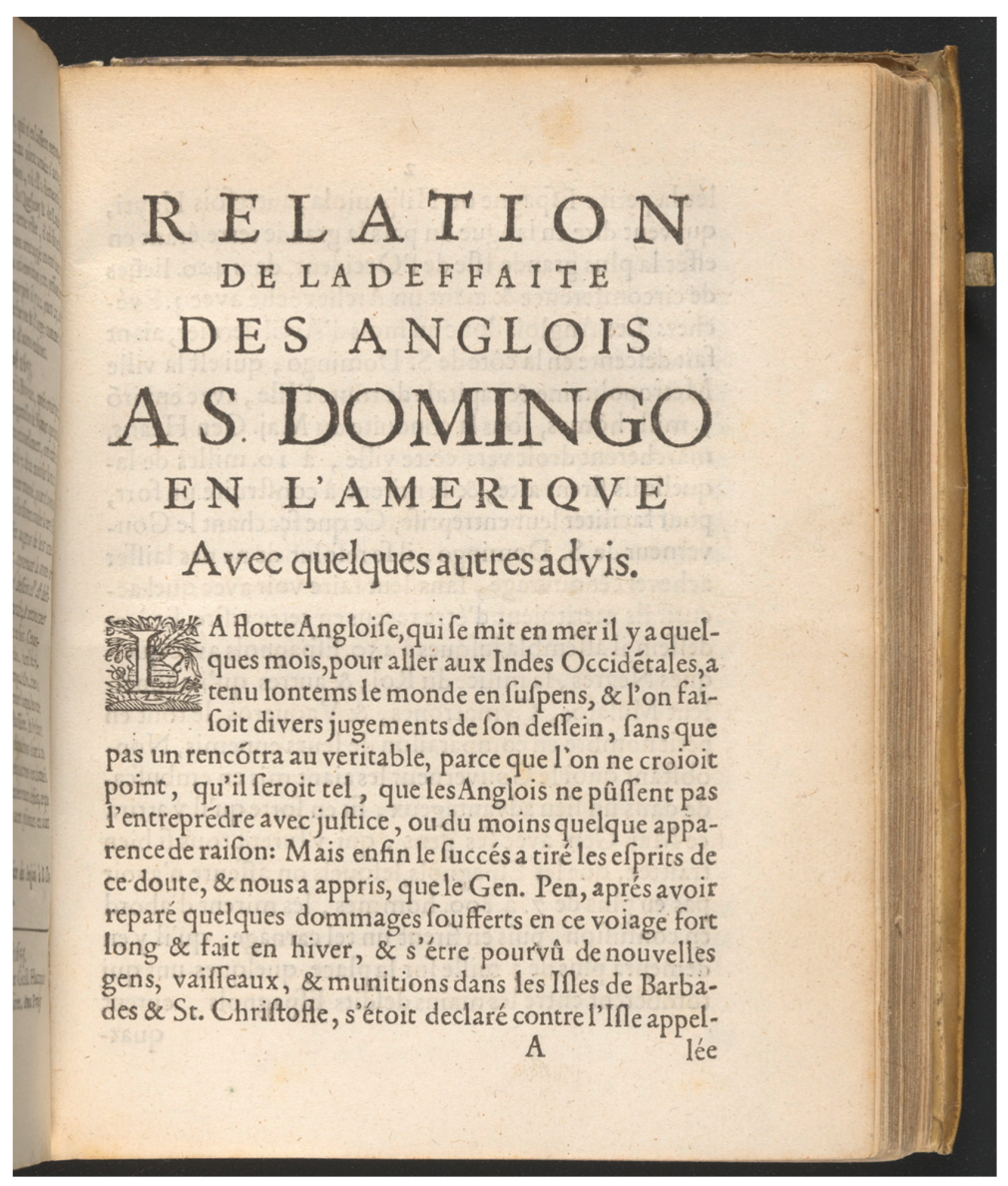

Fig. 2 Pierre Hugonet, Relations véritables, 14 August 1655 (s.n.), p. 1. Copyright Royal Library, Brussels.

(1635-1659) in his newspaper than his French counterpart. However, these Southern Netherlandish newsbooks cannot be seen purely as propaganda instruments: Both Verhoeven's Nieuwe Tijdinghen and Hugonet's Relations véritables were as much informative as commercial products, while government control over the printing press was never absolute. ${ }^{23}$

\section{Presenting Defeat as Future Success}

Offering the readers of the Nieuwe Tijdinghen the latest news on the Dutch activities at sea, and, later on, in Brazil, was a challenging task for Verhoeven in 1624. ${ }^{24}$ For the largest part of the year, uncertainty and lies surrounded the overseas ambitions of the West

23 Arblaster, From Ghent to Aix, 74-79, 114, 221, 247-255; Der Weduwen, 'The Battle of the Downs', 9.

24 Of Verhoeven's Nieuwe Tijdinghen of 1624, 100 of the presumably 142 printed issues that year have been preserved in the collection of the Royal Library of Brussels. These one hundred issues provide the basis of this case study. 
India Company. In the course of August, when the Antwerp printer-publisher probably heard about the Dutch capture of the Brazilian city for the first time, he had to deal with the disastrous outcome for the Spanish Crown and its aftermath in a politically acceptable way. As the privileged news publisher and fervent supporter of the Habsburg international cause, Verhoeven had to take delicate editorial decisions if he wanted to inform his readers while, at the same time, preserving his allegiance to the Spanish Crown. Confronted with initially uncertain and ultimately bad news in 1624, how did the Antwerp publisher present and frame the loss of Bahia to his readers?

In the first half of the year, the plans of the Gentlemen Nineteen were still largely shrouded in mystery in the Habsburg Netherlands, since the Company operated in great secrecy and even intentionally spread lies about the size and the objective of the naval expedition. ${ }^{25}$ Due to the lack of reliable information, Verhoeven initially published only a few varying accounts on the objective and progress of the Dutch fleet. ${ }^{26}$ In his issue of 23 February, the Antwerp courantier reported for the first time that 'the forty-two largely manned [Dutch] ships, which had left port at the end of last year and appeared to be well-equipped for battle, had recently reassembled and were heading for the Americas' ${ }^{27}$ The following day, he revised his account on the Dutch fleet, informing his readers that 'the last [part of the] fleet leaving for the Americas was not yet fitted out, whereas the first [one], consisting of eleven vessels, was heavily damaged'. ${ }^{28}$ During the final days of February, the courantier added that the States-General had even sent out some more ships with ' 4,000 unwilling soldiers' on board. ${ }^{29}$ With the exception of a later report on a meeting of the directors of the wIC concerning their plans for the Americas, Verhoeven did not provide further coverage of the Dutch expedition until August. ${ }^{30}$ The Antwerp courantier was not the only one who kept his readers waiting: his Amsterdam counterparts, Broer Jansz and Jan van Hilten also provided only the occasional reference in the first half of the year. ${ }^{31}$

Nevertheless, Verhoeven kept the Atlantic storyline warm. He shifted his focus from the Dutch naval expedition onto related Habsburgs affairs from the beginning of March onwards, assuring his customers that there was no reason to panic about the Dutch campaign. The newsman underlined several times that Philip IV would continue war against the enemy, on both land and sea, and was already fitting out ships to impede the Dutch

25 Klooster, The Dutch Moment, 40.

26 Verhoeven frequently used the general geographical terms Indies ('Indien') and West-Indies ('West-Indien') when reporting on the Atlantic World. As it is unclear whether he chose these words to refer to the then known Atlantic as a whole or only a specific part, I will use the more general translation 'Americas' in this cases.

27 'en die tweeenveertich Schepen die int eynde vant voorleden Jaer/ met soo vele volckx/ ende preparatie van Oorloghe uit gevaren zijn souden hen wederomme by een vergadert/ ende op de reyse na Indien begeven hebben' in: Nieuwe Tijdinghen (hereafter NT) 19 (Antwerp: Abraham Verhoeven, 23 February 1624), 7.

28 '(Wy hooren dat) de leste Vlote van West-Indien noch niet opghedaen en heeft. De eerste Vlote is seer beschadicht/ die bestont in elf Schepen' in: NT 21 (Antwerp: Verhoeven, 24 February 1624), 3.

29 'vier duysent Musquettiers die men teghen zijnen danck oft wille' in: NT 24 (Antwerp: Verhoeven, 28 February 1624), 6-7.

30 NT 43 (Antwerp: Verhoeven, 12 April 1624), 8.

31 Van Groesen, Amsterdam's Atlantic, 45; Van Groesen, '(No) News from the Western Front', 748. 
on their way to the Americas. ${ }^{32}$ On 22 April, Verhoeven stated that 'the Spanish are trying to protect the Americas to the best of their ability, populating and preparing the coastlines in such a way that the Dutch would not be able to achieve anything anywhere with their ships.' ${ }^{33}$ The courantier also reported extensively on the voyages and cargoes of the Habsburg silver fleets during the summer months. In his issue of 5 July, for example, he enthusiastically informed his readers about the safe arrival of the treasure fleet in Seville in the last week of May, being 'richer than any other one that ever had moored in Spain.' ${ }^{34}$ His shift in focus suggests that he either lacked more news on Dutch activities at sea or in the Americas before August, or that he temporarily decided to cease coverage on the topic and tried to divert his readers' attention away from the Dutch expedition. Either way, Verhoeven actively filled the 'gap' in his Nieuwe Tijdinghen, giving the Atlantic storyline a more positive twist for the Spanish Crown.

By August, when rumours of Dutch success in Brazil reached not only the United Provinces, but also the Habsburg Netherlands, the Antwerp publisher remained very skeptical. ${ }^{35}$ Probably in anticipation of other tidings, or affirmation from the Iberian Peninsula, Verhoeven initially labelled the bad news 'a lie, spread in the United Provinces among the not so bright common people to encourage them to invest in [the building of] new ships, needed to help them [in Brazil]'. ${ }^{36}$ After receiving confirmation of the Habsburg defeat from Portugal at the end of August or, at the latest, the beginning of September, the courantier no longer explicitly denied the Dutch victory overseas, but instead presented it as a Pyrrhic one. According to Verhoeven, the high costs of the expedition vastly outweighed the Dutch haul or direct gains, which were limited to plundered church goods. He added that the seized church properties were mainly made out of copper, lead or tin, and not even out of gold or silver, as was rumoured in the United Provinces. ${ }^{37}$ Furthermore, the courantier reported that the local 'Portuguese, natives, and slaves', who initially had fled Bahia, offered resistance to the Dutch and even started a guerrilla war. ${ }^{38}$ In his issue of 2 October, for example, he mentioned a native ('Indian') attack on the invaders, in which many Dutchmen were killed. ${ }^{39}$ According to Verhoeven, and correctly as it turned out, the Portuguese had even shot Johan van Dorth (1574-1624), the first governor of Bahia and commander of the Dutch land forces, whose death was deeply lamented in the United Provinces. ${ }^{40}$ Thus, the Antwerp publisher concluded that the enemy not only experienced

32 See for example: NT 29 (Antwerp: Verhoeven, 8 March 1624), 5; NT 35 (Antwerp: Verhoeven, 22 March $1624), 3$.

33 'sy [De Spagniaerden] willen de West-Indien naer hun uiterste vermoghen dessenderen/ de Custen sijn ouer al soo bezedt ende versien dat onmoghelijck is de Hollanders met hun schepen yewers yet souden connen uitrechten.' in: NT 47 (Antwerp: Verhoeven, 22 April 1624), 6.

34 'De Vlote is soo rijcke als oyt in Spagnien eene ghecomen is' in: NT 73 (Antwerp: Verhoeven, 5 July 1624 ), 4. 35 Klooster, The Dutch Moment, 41; Van Damme and Deploige, “Slecht nieuws, geen nieuws", 15.

36 't'zijn al leughenen/ men stoyt dit alhier wt/ om datmen beter geven soude/ want men seyt men moet wederom ander Schepen hebben/ om henlieden te secoureren/ ende t'volck is soo bodt dat se niet en dencken dat het is om te ghewilligher te geven... ' in: NT 86 (Antwerp: Verhoeven, 16 August 1624), 5-6.

37 NT 94 (Antwerp: Verhoeven, 13 September 1624), 3-5.

38 'Portugiesen/ Inlanders/ ende Slaven' in: NT 92 (Antwerp: Verhoeven, 11 September 1624), 3-4.

39 NT 97 (Antwerp: Verhoeven, 2 October 1624), 5.

40 NT 109 (Antwerp: Verhoeven, 15 November 1624), 3; Klooster, The Dutch Moment, 40. 
heavier losses than gains in Brazil, but also that they would not be able to hold out for a long time without reinforcements.

Although Verhoeven's reports on the struggle for Bahia often reflected (too) positively upon the Spanish monarchy and its undertakings, they were not entirely unfounded. Whereas the Habsburgs had undeniably suffered an Atlantic defeat, the Dutch, in turn, had difficulties in exploiting and defending their Brazilian stronghold. Lacking manpower and means, and facing growing local resistance, the invaders were increasingly in need of support from Europe. The killing of Van Dorth and the incompetent leadership of his successors, the brothers Albert and Willem Schouten, also had a demoralizing effect on the Dutch troops, limiting further expansion in Brazil. ${ }^{41}$ Compared to the swift capture of Bahia, the actual occupation reinforced the impression that their presence would only be short-lived. Therefore, Verhoeven's decision to refocus attention from the actual Dutch conquest onto its aftermath turned out to be a clever and Habsburgfriendly strategy.

From September onwards, Verhoeven also underlined the grandeur and determination of the Spanish Crown, just as he had done in the first half of the year. By describing the cargoes of the arrived silver fleet in detail in his issue of 22 November, the courantier not only kept his readers abreast of the most important annual shipping news, but also diverted public attention away from the Habsburg defeat. ${ }^{42}$ Moreover, he frequently reported on the large, united counteroffensive that the Spanish and Portuguese were preparing in reaction to the news of the unfortunate events in Brazil. ${ }^{43}$ On 11 September, Verhoeven told his readers that:

His Majesty sends out a formidable Armada [to Brazil], from both Portugal, under [the command of] Don Gaspar de Fagarda and Andalusia, under [the command of] Don Frederico de Toledo, [consisting of] twelve galleons and many other ships and also five from our warships of Dunkirk, may the Lord be with them. It is also said that more than 8,000 soldiers, high noblemen and others will join. I hope, by the grace of God, that the Dutchmen will be beaten, if it pleases Him. ${ }^{44}$

He confirmed this report a month later, adding that the Habsburg fleet would count forty ships in total. ${ }^{45}$ Finally, on 20 December, the Antwerp publisher revised his previous report on the armada, which in total would consist of more ships than the afore-mentioned number of forty, since the Portuguese part already counted forty-four vessels and 'the Castilian [one] will not be fewer in number' ${ }^{46}$

41 Klooster, The Dutch Moment, 41; De Boer, 'De val van Bahia', 43-45.

42 NT 111 (Antwerp: Verhoeven, 22 November 1624), 3-4. For more information on shipping news in Verhoeven's Nieuwe Tijdinghen, see Arblaster, From Ghent to Aix, 157-160.

43 The news of the Dutch capture of Bahia reached the Iberian Peninsula almost a month earlier than the United Provinces, giving the Habbsurg a head start over the Dutch of four weeks for preparing their counter-attack. See Van Groesen, 'A Week to Remember', 28.

44 'Sijne Majesteyt derwaerts seynt een gheweldighe Armade/ soo van Portugael onder Don Gaspar de Fagarda, ende in Andalusia onder Don Frederico de Toledo, 12. Galleonen/ ende veel andere Schepen mede oock vijf van onse Duynkerksche Oorlooghsschepen/ den Heere wil se gheleyden/ men seydt datter over de 8ooo. Soldaeten/ groote Noblesse/ ende andere mede gaen/ Ick hope met de gracie Godts dat de Hollanders wat op haert muts sullen crijghen/ d'welck Godt geven wil.' in: NT 92 (Antwerp: Verhoeven, 11 September 1624), 6.

45 NT 101(Antwerp: Verhoeven, 11 October 1624), 6.

46 'ende die van Castilien en sal niet minder wesen' in: NT 135 (Antwerp: Verhoeven, 20 December 1624 ), 8. 
Even though Verhoeven overestimated the size of the fleet, which in reality consisted of fifty-six ships instead of the suggested minimum of eighty-eight, the so-called 'Voyage of the Vassals' was the largest Habsburg naval force since the Armada of 1588. The counteroffensive was not only remarkable for its size, but also for the close cooperation between the two kingdoms, which were united under one crown since 1580 . For once, the Portuguese and Spanish shared a similar sense of urgency, mobilizing all available forces. ${ }^{47}$ While Verhoeven's extensive coverage of the Iberian counteroffensive undeniably fitted the political agenda of the Habsburg regime, it also had news value for contemporaries. According to the Antwerp publisher, both parts of the armada would set sail on 23 or 24 December and assemble at Cape St. Vincent, situated on the Cape Verde archipelago, before heading for Brazil together. ${ }^{48}$ With this last Atlantic report of 1624 on the Habsburg fleet, he ended the Brazilian storyline on a positive - and promising - note for the Spanish monarchy, forecasting better tidings to come in the following year.

When analyzing Verhoeven's coverage of the prelude to the Dutch capture of Bahia, the actual conquest and its aftermath in 1624, several of his editorial decisions or strategies stand out. Whereas the Dutch victory or Habsburg defeat overseas was an important Atlantic news item that year, it actually received little direct attention from the Antwerp courantier. Verhoeven only briefly touched upon both the Dutch expedition to and the eventual capture of the Brazilian city, giving his readers little concrete information on what had actually happened at sea and overseas. Initially presenting the loss of Bahia as a lie, the newsman eventually did not just deny or ignore the anti-Habsburg news, as argued by Van Damme and Deploige. ${ }^{49}$ Verhoeven, by contrast, downplayed the Dutch victory and (re)focused on the fierce local resistance the invaders encountered in Brazil. At the same time, he frequently emphasized the power and strength of the Spanish monarchy, who appeared to leave nothing to chance to reconquer its former Atlantic possession. Using these different strategies, Verhoeven not only toned down the Dutch achievements overseas, but also minimalized their potential harm to the Habsburg Crown, depicting it more determined and powerful than ever. Thus, he created a one-sided storyline, systematically in favour of the Spanish monarch, subtly turning the suffered defeat into a possible future success.

\section{Turning Failure into Success}

The English fleet, which set sail for the Americas a couple of months ago, has kept the world in suspense for a long time, leaving people guessing about its target. No one managed to find out the truth, since nobody believed the English would carry out such an unjust and unreasonable undertaking. But, finally, these uncertainties have been brought to an end, as word has reached us that General Penn [...] attacked the island of Hispaniola or little Spain, also known as Haiti..$^{50}$

47 Schwartz, 'The Voyage of the Vassals', 735-737.

48 NT 135 (Antwerp: Verhoeven, 20 December 1624), 8.

49 Van Damme and Deploige, 'Slecht nieuws, geen nieuws', 15.

50 'La flotte Angloise, qui se mit en mer il y a quelques mois, pour aller aux Indes Occidentales, a tenu lontems le monde en suspens, \& l'on faisoit divers jugemens de son dessein, sans que pas un rencontra au veritable, parce que l'on ne croioit point, qu'il feroit tel, que les Anglois ne pûssent pas l'entreprendre avec justice, ou du moins 
With these lines, the Brussels newsman Pierre Hugonet started his lengthy report on the English defeat at Hispaniola, which he published in a special issue of his Relations véritables on 14 August 1655. Up to that point, news media on both sides of the English Channel had closely monitored the English fleet from the beginning of 1655 onwards, wildly speculating about its objective and progress. The Protectorate government managed to maintain the secrecy that had surrounded the naval expedition from the start, actively controlling the presentation and dissemination of news concerning the Western Design. Hence, the status of the English expedition remained a mystery in England and on the Continent for the largest part of the year..$^{51}$

Like many other news publishers and intelligence gatherers, the Brussels courantier was preoccupied with suggesting possible targets of the English naval force in the first half of 1655 . His first detailed account appeared on 20 January. Letters from Portsmouth had confirmed that the English fleet, under the joint command of Generals William Penn and Robert Venables and consisting of 'thirty-seven well-equipped warships and additional supply vessels', was heading for the Americas or West Indies since the turn of the year. ${ }^{52}$ Three days later, Hugonet confirmed that the English were initially on their way to Barbados, where 'they would raise additional troops or replace them by Irish colonists' before continuing their voyage. ${ }^{53}$ Even though he soon found out that Barbados, England's most prosperous and populous Caribbean colony at that time, was the first objective of the English naval force, it took him until mid-July to discover its final destination. Like other newsmen, the Brussels courantier suspected that the English targeted the Habsburg territories, considering Cartagena, the major port city of Tierra Firma, or the Amazon region ('païs des Amazones') as possible options in his issue of 10 March. ${ }^{54}$ In April, he abandoned his earlier assumptions and began to present Cuba as the objective of the English expedition. In his issue of 14 July, the courantier even assumed - incorrectly - that the English 'had landed on Cuba and suffered defeat, losing General Penn in battle'. ${ }^{55}$ Although Hugonet picked the wrong island, he actually had been thinking in the right direction in the first half of the year. When Cromwell and his advisors were planning the Western Design, they framed their discussion around Cuba, Hispaniola, and Cartagena, all strategic stepping stones for

quelque apparance de raison: Mais enfin le succés a tire les esprits de ce doute, \& nous a appris que le Gen. Pen [...] s'étoit declaré contre l'Isle appellée la petite Espagne ou Hispaniola, autrefois Hayti' in: Relations véritables (hereafter $R V$ ) s.n. (Brussels: Pierre Hugonet, printed by Willem Scheybels and sold by Guillaume Hacquebaud, for Pierre Hugonet, 14 August 1655), 1-2.

51 Cromwell even imposed stricter press regulations in the fall of 1655. See Greenspan, 'News and the Politics of Information', 1-4, 13-14.

52 ' 37 . bons vaisseaux de guerre, outre les navires, qui portent les provisions' in: $R V$ s.n. (Brussels: Hugonet, 20 January 1655), 35. Hugonet offered his readers more details than the above-mentioned quote suggests, even conveying the departure dates of both parts of the English fleet.

53 'pour y charger encor du monde, ou bien en changer pour les Irlandois, qui y sont' in: $R V 4$ (Brussels: Hugonet, 23 January 1655), 42.

54 Greenspan, 'News and the Politics of Information', 4; RV s.n. (Brussels: Hugonet, 10 March 1655), 120.

55 '(la flotte Angloise du General Pen) aiant débarqué ses gens en l'Isle de Cuba, ils y ont été deffaits \& lui méme tué' in: $R V$ S.n. (Brussels: Hugonet, 14 July 1655), 336. 
further incursions on the Habsburg territories. ${ }^{56}$ Therefore, Cartagena and Cuba were both reasonable guesses.

After six months of conjecture, the Brussels newsman not only adopted a firmer stance in his reporting, but also began to counter accounts that claimed an English victory. On 17 July Hugonet revised his Cuban storyline, assuring his readers that Hispaniola had turned out to be the target of the English fleet. ${ }^{57}$ When the first official reports on the expedition arrived in England, Hugonet acknowledged that rumours about the English capture of Santo Domingo circulated in both the Americas and England. ${ }^{8}$ However, according to the Brussels courantier, there was sufficient reason to doubt the news, since eyewitness reports were still lacking and the overseas events only received scant media coverage in England. ${ }^{59}$ While Hugonet's skepticism can easily be considered as subtle propaganda, it was not misplaced for the time being: when Cromwell was informed about the defeat suffered at Hispaniola and subsequent victory at Jamaica on 24 July, he tried to suppress the news for as long as possible, prohibiting seamen from the ship which had brought the message to come ashore. Even though the Lord Protector's efforts did not prevent the news from slowly trickling out, it would take several more weeks before the complete story emerged in England and on the Continent. ${ }^{60}$

Hugonet first announced the news of the English debacle at Santo Domingo on 7 August, quashing 'the earlier victorious rumours, which were spread out deliberately to hide what we finally know for sure. ${ }^{61}$ A week later, he briefly confirmed his earlier report in his regular newspaper and provided his readers with a special issue on the same day, offering a detailed overview on the past events at sea and overseas. ${ }^{62}$ In this special issue of 14 August Hugonet's allegiance to the Spanish monarchy came to the fore: the courantier glorified the island's governor, the Count of Peñalva, the Habsburg colonists and the local inhabitants for having repelled the enemy together. While the Brussels newsman presented the recently appointed governor as a competent and determined leader, he explicitly praised 'the small number of Spanish and indigenous people, who, inspired by the local, zealous priests, had every confidence in divine providence, attacking the heavily armed invaders as if they were invulnerable.' ${ }^{63}$ The English, according to Hugonet, even though they had strongly outnumbered their opponents, had been slaughtered, losing 3,000 men in Peñalva's well-planned ambush alone. ${ }^{64}$

56 Pestana, The English Conquest of Jamaica, 65-66.

57 RV 29 (Brussels: Hugonet, 17 July 1655), 343-344.

58 Greenspan, 'News and the Politics of Information', 7-8; RV 30 (Brussels: Hugonet, 24 July 1655), 355.

59 See the following issues: $R V 30$ (Brussels: Hugonet, 24 July 1655), 355; $R V 31$ (Brussels: Hugonet, 31 July 1655), 367; RV 32 (Brussels: Hugonet, 7 August 1655), 379.

60 Greenspan, 'News and the Politics of Information', 7-9.

61 'les nouvelles des semaines passées ont été semées à dessein, pour celer ce que l'on a enfin appris avec certitude' in: RV 32 (Brussels: Hugonet, 7 August 1655), 379.

62 See $R V 33$ (Brussels: Hugonet, 14 August 1655), 390; RV s.n. (Brussels: Hugonet, 14 August 1655), 1-4. 63 'ce petit nombre d'Espagnols \& de ces autres peoples, qui par les exhortations ferventes \& zelées des Ecclesiastiques de S. Domingo, avoient pris une si grande confiance en la justice de leur cause, qu'ils se mélerent parmi les Anglois, avec aussi peu de crainte de leurs armes, qu'ils eussent été invulnerables' in: $R V$ s.n. (Brussels: Hugonet, 14 August 1655), 4.

64 RV S.n. (Brussels: Hugonet, 14 August 1655), 3. 
While his report on the struggle for Hispaniola was too black-and-white and reflected too positively upon the Habsburg achievement, it quite accurately captured the essence of the events in the Caribbean: a modest group of islanders and 200 Spanish soldiers, pre-emptively sent from Spain to strengthen the island, managed to hold off an invasion force that initially ranged between 7,000 and 9,000 men. ${ }^{65}$ Although the Brussels newsman underestimated the role of illness in the struggle for Hispaniola, eventually claiming more lives than the actual fighting, the English troops did experience considerable losses. ${ }^{66}$ The unexpected Habsburg success against an overwhelming English majority stunned friend and foe alike, leaving 'the other [English] expedition members in great consternation', as the Brussels courantier observed correctly. ${ }^{67}$

While Hugonet's coverage of the Hispaniola debacle already showed his loyalty to the Spanish Crown, it became even more apparent in his reporting on the Jamaican episode, which did not have such a favourable outcome for Philip IV. In his entire special issue of 14 August, the courantier did not mention the English achievement at Jamaica at all. He conveyed only briefly that the English survivors, who were in a bad condition, probably had withdrawn to the neighbouring Caribbean island ${ }^{68}$ Although it cannot be ruled out that news of the English capture of Jamaica had not yet reached Hugonet on 14 August, it certainly had by the beginning of September. In his issue of 4 September, he stated that reports were circulating in London, still denying the defeat at Hispaniola and proclaiming the seizure of Jamaica. Due to the deplorable state of the remainder of the English army, Hugonet strongly doubted the veracity of the English accounts, dismissing them as 'complete fiction'. ${ }^{69}$ For the rest of the year, he maintained this line of reporting, deliberately suppressing the news of a Spanish defeat in the West Indies.

Instead, Hugonet put a pro-Habsburg spin on the Jamaican storyline from September onwards, using different editorial strategies. The courantier mainly occupied his readers with the continuing miseries and misfortunes of the remaining expedition members, who were left to their own devices by Generals Penn and Venables. ${ }^{70}$ In his issue of 2 October, for example, he stated that 'the survivors were close to despair,

65 Pestana, The English Conquest of Jamaica, 71, 83, 88; Greenspan, 'News and the Politics of Information', 4.

66 The English expedition leader Venables oscillated between 700 or 1,00o casualties and estimated the amount of people who succumbed to illness to be much higher, concluding that only 2,00o survivors were fit to continue the overseas campaign. Compared to other eyewitness accounts, Venables' esitimates of the English losses were not surprisingly the most modest ones, making the eventual death rate even higher. See Pestana, The English Conquest of Jamaica, 88-89.

67 'les autres de cette entreprise sont dans une grande consternation' in: RV s.n. (Brussels, Hugonet, 14 August 1655), 3 .

68 RV s.n. (Brussels: Hugonet, 14 August 1655), 3.

69 'force particularitez nouvellement controuvées' in: RV 36 (Brussels: Hugonet, 4 September 1655), 426.

70 Hugonet also reported extensively on the departure, return voyage and arrival of the English expedition leaders. Their decision to return and subsequent abandonment of the remaining English troops sparked great controversy in the West Indies and England. Once Penn and Venables had safely arrived in London, they were imprisoned in the Tower and faced sentencing, since Cromwell was strongly displeased with their actions. For more information, see Pestana, The English Conquest of Jamaica, 133-138. 
fearing that they would never return to England or perish on the island'. ${ }^{11}$ Four days later, Hugonet added that 'those who searched for the enemy in the mountains [...], were killed or taken captive by the Spaniards and therefore, given up for lost' ${ }^{72} \mathrm{He}$ also seriously doubted if the decimated English forces would get the outside help they desperately needed in time, since both the neighbouring islands and the nearest mainland belonged to the Habsburg empire. ${ }^{73}$ Whereas the English made great efforts to send additional troops and supplies to Jamaica, the recruiting of volunteers appeared to be increasingly difficult, according to the Brussels newsman. On 6 November, he noted that the English government had to cajole people into leaving for the Caribbean island, as 'they knew the deplorable state the survivors were in and the misery they endured, mainly caused by the poor air quality' ${ }^{74}$

Even though Hugonet presented a too negative image of the condition of the English troops, his depictions were not entirely misinformed. The invaders indeed continued to endure illness and hunger, receiving only few reinforcements from both England and New England. ${ }^{75}$ Although these conditions seriously hindered the English in their conquest of Jamaica, they did not stop them from capturing a vital part of the Caribbean island. Soon, the invaders managed to gain control over the principal town of Santiago de la Vega and the Old Harbor Bay, holding much of the territory that the Jamaican residents had actively utilized. While they succeeded only in a partial seizure in 1655, the English had a strategic stronghold from which they could gradually continue to conquer and colonize Jamaica. However, their presence was not left unchallenged: Whereas some of the inhabitants fled to the neighbouring island Cuba, many tried to reclaim their island, gradually mounting a guerilla war against the invaders. ${ }^{76}$

Hugonet withheld accounts underlining the English achievements at Jamaica, and, by contrast, focused on the upcoming Jamaican counter-attack in his Relations véritables. According to the courantier, the Spanish inhabitants had withdrawn strategically into the mountains and were 'waiting for some reinforcement to get rid of their new guests' ${ }^{77}$ In the same report, published on 6 October, he implied that the Habsburgs were anything but afraid of the invaders, killing or capturing the ones who came close to their temporary refuge. ${ }^{78}$ By 17 November, the courantier assured his readers that the awaited reinforce-

71 'ceux, qui sont demeurez en la Jamaïcque, où ils sont en si mauvais état, qu'ils desesperent d'en jamais retourner, \& d'y pouvoir demeurer lontemps en vie' in: $R V 40$ (Brussels: Hugonet, 2 October 1655), 474.

72 'ceux, qui s'approient des montagnes [...] pour en chercher, étoient aussitôt tuëz, ou fait prisonniers, en sorte qu'on tenoit ces gens là pour perdus' in: $R V$ s.n. (Brussels: Hugonet, 6 October 1655), 476.

73 RV 44 (Brussels: Hugonet, 30 October 1655), 518.

74 'on sçait le mauvais état, auquel ils se trouvent, \& les miseres, qu'ils y souffrent, à cause principalement que l'air y est fort, mal sain' in: $R V 45$ (Brussels: Hugonet, 6 November 1655), 531.

75 Since only few English supply ships had reached Jamaica, General Penn ordered three vessels to sail for New England to buy provisions. Due to various delays, the first of the three ships arrived only five months after it had been dispatched. As a result, the expedition members faced the continued possibility of starvation. See Pestana,

The English Conquest of Jamaica, 131-132.

76 Pestana, The English Conquest of Jamaica, 128-132.

77 'des montagnes (où les Espagnols s'étoient retirez attendant quelques secours, pour se deffaire entiérement de ces nouveaux hôtes)' in: $R V$ s.n. (Brussels: Hugonet, 6 October 1655), 476.

78 RV S.n. (Brussels: Hugonet, 6 October 1655), 476. 
ments had arrived, as it was rumoured that the English troops were defeated and their remaining ships captured by Habsburg colonists from the adjacent islands and Tierra Firma. ${ }^{79}$ Without specifying how and by whom the enemy had been vanquished, he confirmed the victorious rumour a week later. ${ }^{80}$ With the exception of one later report, briefly covering the release of General Penn and Cromwell's justification for his actions in the West Indies, Hugonet ended the Jamaican storyline on a positive note for the Habsburgs in $1655 .^{81}$

Hugonet's reports on the Jamaican counteraction diverged considerably from the actual overseas events: Even though the Jamaican inhabitants did not give up their island without a fight and relied on support from the neighbouring islands, they did not manage to repel the English invaders successfully, either in 1655 or in the following years. Nevertheless, the Brussels newsman used the rumours surrounding the ongoing guerrilla war to his advantage, systematically suggesting an outcome in favour of the Spanish Crown from November 1655 onwards. Maintaining this line of reporting in the beginning of the following year, the Brussels newsman continued to credit the Habsburgs with a second Atlantic victory. ${ }^{82}$ Therefore, the way in which the courantier dealt with (partial) defeat in 1655 and the beginning of 1656 could easily be portrayed as pure propaganda: he blatantly discarded news accounts claiming an English victory; he covered only part of the story and gradually - and even falsely - turned the struggle for Jamaica into a new Habsburg success story.

However, Hugonet's reporting is better understood as strategical, informed guesswork in a climate of scarce, unsubstantiated, and contradictory rumours and information. Both in England and on the Continent, news concerning the situation in Jamaica remained problematic in the final months of 1655 as well as in the following years, reinforcing the belief that the English had been forced to abandon the island. ${ }^{83}$ At the same time, a strong Habsburg counter-attack was not beyond the bounds of possibility, especially after the Spanish declaration of war in March $1656 .{ }^{84}$ In this atmosphere of uncertainty and animosity, Hugonet created a storyline that followed naturally from his earlier line of argument in 1655: since the Habsburgs had managed to hold off the hitherto invincible English army once, a second success could not be ruled out.

79 RV S.n. (Brussels: Hugonet, 17 November 1655), 547-548.

80 RV S.n. (Brussels: Hugonet, 24 November 1655), 560.

81 Up to issue number 49, almost all regular issues of Hugonet's Relations véritables have been preserved in the collection of the Royal Library of Brussels. Issue number 49, which was published on 4 December, is, however, the only remaining copy for December 1655. According to Paul Arblaster, Hugonet's publication was suspended from 4 December 1655 to 22 January 1656 for unknown reasons so far. See Arblaster, From Ghent to Aix, 222. 82 In his issue of 29 January 1656, for example, the Brussels courantier once again confirmed the Habsburg success, adding that that the English had retreated to the Caribbean island Barbados. See $R V 2$ (Brussels: Hugonet, 29 January 1656), 19.

83 There was only little news to report on Jamaica from October 1655 until Cromwell's death in September 1658 , leaving both news publishers and readers guessing about the condition of the Caribbean island. See Greenspan, 'News and the Politics of Information', 16.

84 Greenspan, 'News and the Politics of Information', 2, 15-16. 


\section{Similar Strategies, Comparable Discourses}

Verhoeven and Hugonet, the two Southern Netherlandish newspaper monopolists of the first half of the seventeenth century, covered the main Atlantic news stories of 1624 and 1655 respectively in a strikingly similar way. From January until August, when reliable reports on the Dutch and English campaigns were scarce, the courantiers had to be creative to fill the vacuum in their newspapers. In 1624, the Antwerp newsman initially published some incoherent accounts on the objective and status of the Dutch fleet, but soon refocused on related Habsburg affairs. In 1655, Hugonet mainly occupied his readers with possible targets of the English naval force, owing more to informed guesswork than to actual knowledge. By the beginning of August, when the two newsmen were confronted with reports claiming an overseas success for the enemy, they first challenged the victorious rumours, dismissing them as lies or false fabrications. As the Dutch capture of Bahia and partial English seizure of Jamaica were too delicate to present in print, Verhoeven only briefly mentioned the defeat, whereas Hugonet blatantly ignored it. As adherents of the Habsburg cause, the courantiers, instead, kept silent about the overseas confrontations, leaving their customers guessing about what had actually happened in the Western Hemisphere.

Verhoeven and Hugonet did not retreat into silence in their newspapers, however, but continued their reporting until the end of the year. Adopting different editorial strategies, they gave the Atlantic storylines a more positive twist for the Habsburg Crown. First, the newsmen downplayed the enemy's overseas achievements. In 1624, the Antwerp courantier presented the Dutch victory as a Pyrrhic one and continually stressed the difficulties the Dutch invaders faced in Brazil, reinforcing the impression that their presence would only be short-lived. In 1655, the Brussels newsman mainly focused on the deplorable state of the English army after the Hispaniola debacle, ruling out the possibility of lasting success in the West Indies. Second, the courantiers prominently featured reports that highlighted the power of the Habsburgs. Both newsmen not only promoted positive images of the Habsburg colonists, who appeared to be eager to fight to reclaim their territories, but also emphasised other accomplishments of the Habsburg monarchy. Just like Verhoeven, Hugonet also kept his customers updated on the voyages of the annual silver fleets, which, according to the courantiers, proceeded almost unhindered in 1624 and 1655 . Thus, the two newspaper monopolists ended their line of reporting on a positive note for the Habsburg monarchy, crediting it with a future or false Atlantic victory by the end of the year.

Verhoeven and Hugonet not only used similar editorial strategies to present the Atlantic news stories to their readers, but also related them directly to European events. In 1624, Verhoeven incorporated the struggle for Bahia into his coverage of the ongoing Dutch Revolt. Throughout the year, he underlined that Philip IV was 'fighting the Dutch on both land and sea to the best of his abilities' several times. ${ }^{85}$ Also, the Antwerp courantier systematically portrayed the Dutch as the Habsburg enemy in his reports on the overseas events.

85 'men de Oorloghe opt alder sterckste te water ende te Lande tegens de Hollanders soude voeren' in: NT 29 (Antwerp: Verhoeven, 8 March 1624), 5. 
When Verhoeven reluctantly conceded that the Dutch had captured the Brazilian All Saints' Bay in the beginning of September, for example, he continually referred to the Dutch as 'the enemy'.8 The Antwerp newsman made the connection between the events in the Low Countries and the Americas even more apparent in 1625, when he affirmed the recapture of Bahia (30 April 1625) and the surrender of Breda (2 June 1625) in the same report. ${ }^{87}$

Likewise, Hugonet framed the Western Design and the blockade of Cadiz as one large English naval campaign against the Habsburg Crown. In May 1655, Robert Blake, the famous English General-at-Sea, was ordered to intercept the flota de Indias, in case Generals Venables and Penn had missed it, and to prevent reinforcements from being sent from Spain to the Caribbean. ${ }^{88}$ According to the Brussels newsman, 'Blake's naval force had lain at anchor at Cadiz since 12 June, hindering the Spanish fleet to leave for Havana'. ${ }^{89}$ The English cruising, which continued during the summer months, seriously delayed the voyages of the Spanish treasure fleets, but eventually did not prevent their safe arrival in Spain. Hugonet concluded that the English campaigns both in Europe and the West Indies had failed, only bringing disaster upon the English since 'they had made themselves powerful enemies and almost destroyed their entire foreign trade.'90 As Hugonet's bulletins showed, hostilities between the Habsburgs and the English were gradually growing. However, the Spanish Crown was only officially at war with England from March 1656 onwards. ${ }^{91}$ Therefore, the Brussels courantier maintained a cautious stance in his reporting in 1655 . Unlike Verhoeven, he did not present the English as an Habsburg enemy (yet), but depicted them as an important opponent.

The two courantiers also adopted a slightly different style of reporting. Verhoeven mainly transferred the incoming or available news from overseas, leaving the interpretation of conflicting accounts to his readers. ${ }^{92}$ Hugonet, by contrast, corrected flaws in his coverage of the Western Design. In early August, when the first reports on events in the Caribbean reached the Southern Netherlands, the Brussels courantier initially stated that 'General Pen (sic) had died, together with 4,0oo of his men, when he carried out the attack on Santo-Domingo'. ${ }^{93}$ Two issues later, Hugonet explicitly revised his earlier assumptions, confirming that the English General appeared to be alive, since 'he had stayed aboard' during the fighting. ${ }^{94}$ By correcting contradictory reports, the Brussels newsman not only created a more coherent Atlantic storyline, but also helped his customers in their understanding of the overseas events of 1655 .

86 NT 92 (Antwerp: Verhoeven, 11 September 1624), 3-6.

87 NT 71 (Antwerp: Verhoeven, 30 July 1625), 3-5.

88 Capp, Cromwell's Navy, 95.

89 'General Blake étoit arrivé et s'étoit ancré devant cette ville là, \& que la flotte, destinée pour la Havane, en devoit sortir' in: $R V$ s.n. (Brussels: Hugonet, 28 June 1655), 360.

90 'que de nous [les Anglois] avoir sucité de puissants ennemis, \& Presque ruiné tout le commerce de nos marchands ' in: $R V 43$ (Brussels: Hugonet, 23 October 1655), 506-507. With this report, Hugonet clearly referred to the embargo Philip Iv had issued against English shipping in September 1655.

91 Greenspan, 'News and the Politics of Information', 2, 14-15; Greenspan, Selling Cromwell's Wars, 99.

92 Arblaster, From Ghent to Aix, 222.

93 'ce General (Penn) a été attaquer San Somingo en l'isle Hispaniola, mais qu'il y a laisse la vie avec 4. mille de ses gens' in: $R V 32$ (Brussels: Hugonet, 7 August 1655), 379.

94 'General Pen, qui étoit demeuré sur ses vaisseaux' in: RV s.n. (Brussels: Hugonet, 14 August 1655), 3. 
However, the aforementioned similarities between the reporting of the two gazetteers strongly outweigh the differences. While Verhoeven and Hugonet greatly differed in professional background, targeted different readerships, and engaged in the newspaper trade decades apart, they covered the Atlantic defeats of 1624 and 1655 respectively in largely the same way in their newspapers. Using similar strategies and comparable discourses, they tried not only to limit the damage to the Habsburg Crown, but also to provide their customers with credible news stories. As a result, both newsmen carefully ignored the actual struggles in the Atlantic world and focused on the aftermath of the overseas confrontations, which looked bleak for the invaders. In both cases the courantiers clearly adopted a pro-Habsburg stance in their reporting, and yet their accounts offered - and still offer - valuable insights into the Atlantic events of 1624 and 1655.

\section{Epilogue: Towards a Discourse of Defeat}

From this comparative research, two main conclusions can be drawn. First, the Antwerp and Brussels monopolists dealt with defeat in strikingly similar ways, despite their different professional backgrounds and targeted readerships. Also, the Southern Netherlandish newsmen appeared to have treated bad news from overseas with the same caution as anti-Habsburg tidings on the Continent, covering them alike in print. This suggests that there appeared to be a 'discourse of defeat' in the Habsburg Netherlands, which newspaper publishers adapted to satisfy both their customers and central authorities throughout the seventeenth century. This 'discourse of defeat', however, was not confined solely to the southern provinces. Recent research has shown that Dutch and English courantiers, who enjoyed greater press freedom than their Southern Netherlandish counterparts, also covered up political or military setbacks, using largely the same editorial and rhetorical strategies. ${ }^{95}$ Secondly, and more importantly, scholars have underestimated the obvious similarities between newspaper publishers inside and outside the Low Countries so far. Therefore, government control and pre-emptive censorship continue to be considered dominant features of the Southern Netherlandish media landscape, even though they appear to have played a less decisive role in the way newsmen covered defeat than hitherto has been presumed. A greater focus on the expectations or wishes of European newspaper readers is, therefore, strongly recommended.

\section{Bibliography}

Andrien, Kenneth J., 'The Spanish Atlantic System', in Jack P. Greene and Philip D. Morgan (eds.), Atlantic History. A Critical Appraisal (New York 2009), 55-79.

Arblaster, Paul, 'Policy and publishing in the Habsburg Netherlands, 1585-1690', in Brendan M. Dooley and Sabrina A. Baron (eds.), The Politics of Information in Early Modern Europe (London 2001), 179-198.

95 Der Weduwen, The Battle of the Downs, 6; Van Groesen, 'A Week to Remember', 49; Greenspan, 'News and the Politics of Information', 8-11. 
Arblaster, Paul, From Ghent to Aix. How They Brought the News in the Habsburg Netherlands, 1550-1700 (Leiden 2014).

Boer, M.G. de, 'De val van Bahia, Tijdschrift voor Geschiedenis 58 (1943), 38-49.

Boxer, Charles R., The Dutch in Brazil, 1624-1654 (Oxford 1957).

Capp, Bernard, Cromwell's Navy. The Fleet and the English Revolution, 1648-1660 (Oxford 1989).

Greenspan, Nicole, 'News and the Politics of Information in the Mid Seventeenth Century: the Western Design and the Conquest of Jamaica', History Workshop Journal 69 (2010/1), 1-26. DOI: 10.1093/HWJ/ DBP027.

Greenspan, Nicole, Selling Cromwell's Wars: Media, Empire, and Godly Warfare 1650-1658 (London 2012).

Groesen, Michiel van, 'A Week to Remember: Dutch Publishers and the Competition for News from Brazil, 26 August - 2 September 1624', Quaerando 40 (2010), 26-49. DoI: 10.1163/001495210X12561886980 239.

Groesen, Michiel van, 'Lessons Learned: The Second Dutch Conquest of Brazil and the Memory of the First', Colonial Latin American Review 20 (2011/2), 167-193. DoI: 10.1080/10609164.2011.585770.

Groesen, Michiel van, '(No) News from the Western Front: The Weekly Press of the Low Countries and the Making of Atlantic News', Sixteenth Century Journal 44 (2013/3), 739-760.

Groesen, Michiel van, Amsterdam's Atlantic. Print Culture and the Making of Dutch Brazil (Pennsylvania 2017).

Israel, Jonathan I., The Dutch Republic and the Hispanic World, 1606-1661 (Oxford 1986).

Klooster, Wim, The Dutch Moment. War, Trade, and Settlement in the Seventeenth-Century Atlantic World (Ithaca NY 2016).

Nieuwe Tijdinghen (NT) (Antwerp: Abraham Verhoeven, 1624).

Nieuwe Tijdinghen (NT) (Antwerp: Abraham Verhoeven, 1625).

Pestana, Carla G., The English Conquest of Jamaica: Oliver Cromwell's Bid for Empire (Cambridge MA 2017).

Relations véritables (RV) (Brussels: Pierre Hugonet, printed by Willem Scheybels and sold by Guillaume Hacquebaud, for Pierre Hugonet, 1655).

Relations véritables (RV) (Brussels: Pierre Hugonet, printed by Willem Scheybels and sold by Guillaume Hacquebaud, for Pierre Hugonet, 1656).

Schwartz, Stuart B., 'The Voyage of the Vassals: Royal Power, Noble Obligations, and Merchant Capital before the Portuguese Restoration of Independence, 1624-1640', The American Historical Review 96 (1991/3), 735-763.

Van Damme, Kristin, and Jeroen Deploige, 'Slecht nieuws, geen nieuws. Abraham Verhoeven (1575-1652) en de Nieuwe Tijdinghen: de periodieke pers in de Zuidelijke Nederlanden tijdens de vroege zeventiende eeuw', BMGN - Low Countries Historical Review 1 (1998), 1-22.

Weduwen, Arthur der, 'The Battle of the Downs. Reporting victory and defeat in the early periodical press', Media History (2016), 1-25. DOI: 10.1080/13688804.2016.1209404.

Weduwen, Arthur der, Dutch and Flemish Newspapers of the Seventeenth Century, 1618-170o, 2 vols. (Leiden 2017). 